\title{
Feminists across Borders: Transnational Feminism, Knowledge Production and University Education in Nigeria
}

\author{
Molatokunbo Seunfunmi Olutayo, Ph.D \\ Institute of African Studies \\ University of Ibadan, Ibadan, Nigeria \\ Abena Asefuaba Yalley, Ph.D \\ Zukunftskollege/Department of History and Sociology \\ University of Konstanz \\ Konstanz, Germany
}

\begin{abstract}
In spite of the various waves of feminism, the unequal status of women persists. One major gain of feminists, however, is the rate at which the spread and influence now pervade the whole world. More importantly, however, is the contributions of indigenous stakeholders to this movement. This contribution is most apt in transnational feminism which recognises the importance of local centers in advancing the feminist movements. Though a lot has been said about the various histories, emergence and basic arguments of the various movements, there is, however, a gap in scholarly literature on the impact of the centers on knowledge production in Nigerian Universities which this paper attempted to fill. This paper traced the impact of transnational feminism activities on knowledge production in Nigerian Universities through a historical analysis of the development of different Women /Gender studies discourse in some Universities. The findings of this study showed that transnational feminism actually expanded scholarship in knowledge and even gave birth to gender studies in most institutions of learning in Nigeria.
\end{abstract}

Keywords: Transnational feminism, knowledge production, gender, university education

\subsection{Introduction}

Until recently, there have been various attempts by different feminist groups all over the world to change the unequal situation of the womenfolk compared to their male counterparts and bring about positive impacts in their lives. As a result, women from different continents at different periods came together bringing to light the subordinate position women have been in over the years. The driving force behind feminism since its inception in the 16th century has been the elimination of societal norms and practices that militate against the entire development and wellbeing of women. Akorede (2011:19) states that "feminist ideology rests firmly on the proposition that women should be given equal rights and opportunities as men". She again reveals that the underlining purpose of feminist ideologies is that human rights, responsibilities, status, and priviledges must not be on the basis of sex

In short, feminists fought for the equal representation of women. The origins of the feminist movement are found in the abolitionist movement of the 1830s (Bryson, 2003:16). The basis of their argument was gender equality and equity at all fronts. Feminist movements came in different waves and strands which are informed by the cultural belief, class, gender identities as well as different races across the globe.

In many ways, the various strands and arguments of feminism have impacted on scholarship in institutions in Africa. Literature is replete on different issues on feminist actions and how it has transformed the lives of women in many forms over the years (Hasso, 2001; Akorede, 2011). However, there is a dearth in literature on how feminism, specifically transnational feminism has impacted knowledge production in Universities which this paper aims to fill. This paper examines the emergence of gender centres in three Nigerian Universities with a view of demonstrating how trans-national feminism has both informed its existence as well the extent to which the centres have used the aims of trans-nationalism to enhance knowledge production in Nigeria.

\subsubsection{History of feminism and feminist movements}

Literature on women's movements focus on various types and forms of women's mobilization and its diverse impacts on women's lives (Hasso,2001 and Mukherjee, 2008). However various scholars have distinguished feminists movements from other types of women's mobilization by asserting that feminist movements or campaigns are largely a subset of women's movements aimed at challenging patriarchy and gender inequality (Beckwith, 2000). 
The international women's movements were pioneers of activism beyond national borders since the struggle for suffrage in the late nineteenth century. The starting point for the history of feminism can be said to be the mid-fifteenth Century (Millet, 1997; Bock, 2002:13). It is pertinent to note that prior to this time individual women attempted to debate women's social position amongst whom was Christine de Pizan, through her writings. Over the years, more women were excited and later started having different movements (Claire, 2008:36). Women's movements in America were classified into epochs with peculiar ideas. The suffrage movement was the first phase, the second phase was the patriarchal deconstruction in 1960 while the third phase begun in the mid-1990s to the present (Evans, 2003). The Feminist scholars and historians divided the history of the movement in the West into three waves (Banks, 1980:26). Each wave is a distinct movement with different goals and objectives as well as peculiar basis of arguments (Hill, 1990: 25). Feminists in each wave viewed themselves as both building on and improving the waves that preceded them.

The first wave of feminism marked the emergence of feminism and feminist action. The middle class and white women constitute this early movement. The main focus of this movement was on how women would gain their right to vote and participate in politics (Rupp, 1998; Hannam, 2007). The early movement comprised white-middle class women who advocated for political rights, precisely suffrage and their struggle addressed women's political equality and representation in government (Randall, 1985:27; Woolf, 1991:70, Gerhard, 2002:321). This wave is considered to have ended when women won the right to vote (Bryson, 1997:18; Hewitt, 2010:10 and Bryson, 1997:18).

The second wave feminist movements (the 1960s -1970s) developed in the industrialized western societies. The major fight during this period was focused on improvement in women's status (De Beauvoir, 1953; Summel, 2000; Friedan, 1963). They addressed issues of equality in education, careers and employment as well as equality in the family and women's reproductive rights (Mitchell, 1997; Smith, 1990). Critical to these was the identification and elimination of all sources of sexism and gender oppression, through different feminist strands (Hawkes worth, 2006:48).

The third wave feminism began in the 1990s and it emerged as a reaction to the second wave. Feminists of this movement who were mostly young women tended to be more global and multicultural (Gills and Munford, 2004; Thompson, 2010). They recognized the advances made by the second wave and tried combating issues on women portrayals in the media. In addition, there was an attempt to fight against all forms of inequalities in the society, influence in politics and stereotypes about media portrayals of women (Claire, 2008;Rowbothan, 1989; Gamble, 2001).Critical analysis of feminism and feminists movements reveals a progressive emergence of a fourth wave feminism across the globe since 2008. Modern-day feminism builds on the former waves of feminism, yet is quite distinct from the former waves as it aligns with the contemporary world and the use of modern-day tools for advocacy. Although some critics believe that there is nothing like a fourth wave because there has not been any formal inauguration of a new wave of feminism, a critical analysis of the emerging trend in feminists' concepts, ideologies and struggle indicates an emergence of a fourth wave feminism. A critical feature of the fourth wave is the use of technology and media as a tool for advocacy. The use of the internet and social media has been a major tool used by present-day feminists to fight patriarchy and inequality. This is because the world has become a global village and the internet has become the fastest way of disseminating information. Worldwide including Africa, the fight against gender inequality, violence against women and rights of women have been publicized through the use of Information Communication and Technologies (ICT). The free flow and access to information have made it easier for the western world to incorporate struggles and needs of Africans into the feminism agenda. They are therefore not ignorant about ongoing issues confronting the African woman. Baumgardner (2011) states that internet has created a global feminist solidarity in the fourth wave. It is thus not surprising that western donors have shown their solidarity to African feminism by sponsoring projects and programmes that promote the rights of women. Social media has been used in several cases to pressure stakeholders into taking immediate actions on the plights of women in Africa. Further to this, the struggles of the fourth wave encompass a wider concept of equality and fairness. The current wave has extended its fight for equality to include the removal of the structures that limit the potentials of women. Politically, the struggles of the fourth wave centre on the implementation of laws and protocols that call for equal representation in governance. Further to this, the new wave is characterized by solidarity with other social justice activists thereby including men in the campaign.

\subsubsection{African Feminism}

Although feminism may seem a foreign word in African, the ideal concept of feminism is not new to the African society. African women have been involved in championing the course of women with some taking up masculine roles and challenges even before colonization. Adjepong (2016) has affirmed that women were active participants in precolonial development of Africa. A woman like Yaa Asantewa of Gold Coast (now Ghana) was very famous for her role in leading the Ashante army who were men to defeat the British army. YaaAsatewa's role in Ashante history is very critical because she challenged the popular gender stereotype of confining women to only domestic work. During the colonial era, women were actively involved in the fight against colonialism. 
Among such women were Funmilayo Kuti of Nigeria, Sally Mugabe of Zimbabwe, Abertina Sisulu and Lilian Ngoyi (both from South Africa) (Rampton, 2015). After independence, Feminism in Africa sprung up during the landmark of the UN decade for women between 1975 and 1985. Since this period, African feminism continues to expand in literature, law and policies (Rampton, 2015). Postocolonial feminism in Africa is characterized by the fight against male domination and inequality. Typical to this is the fight against gender-based violence, traditional practices that are harmful to women, property and inheritance rights, equality in education and equal participation in governance. A major tool was advocacy, lobbying and activism. It was during this era that the African continent realized the springing up of several civil society groups and non-governmental organizations that sought to promote the rights of women.

\subsubsection{Transnational Feminism}

Transnational feminism began in the 1970s as a result of the different discussions of feminism and gender issues (Mendoza, 2002; Baksh and Harcourt, 2015). It emerged when feminists realized that the movement has expanded to the developing countries and has become universal phenomenon (Hewith, 2010:11; Roces and Edwards, 2010). Transnational feminism was birthed by feminism which is now on a trans-national scope. Motta, et al, (2011) all contend that transnational feminism arose from liberal feminists' ideologies which contend that household and traditional roles ascribed to women are tools of oppression, thus women should break this form of oppression by being educated. Its root is predominantly a western school of thought. Reilly (2001) opines that this form of feminism grew when scholarship on feminism expanded and awareness increased. Transnational feminism comes as a reaction to global feminism (Laut,2014). Transnational feminist theories are a branch of feminism with the ideology of addressing specific feminist concerns. It is borne out of the idea that cross border feminism can occur and common differences can form solidarities in ways that combat unequal relations that exist among feminists. Literature has shown that there are major concerns of transnational feminism that make it distinct from others. Di Marco and Tabbush (2011:34) contend that a major distinctive feature of transnational feminism is the concept of 'gender'. They explain that transnationalism employs the use of women and women's interactions to understand women's experiences. Moreover, it also examines how colonialism, which is viewed as the most important area of concern for transnational feminism is about and examines colonial histories, postcolonialism situations and roles of women, modernization, human rights, imperialism and how feminist movements have perpetuated or addressed gender divisions. Finally, gender was examined in connection with how colonial powers socially constructed conceptions of masculinity and femininity among the colonized, as well as the roles colonizers played on gender roles and conceptions of gender (Connel, 2014)

In the words of Abiola (2006:61), there exists:

a cord that links us all and which connects us across distances, time zones, [and] worlds. This cord, however, also connects the different aspects of who we are.

\subsubsection{Impact of Transnational Feminism}

The major impact of the activities of transnational feminism is the emergence of various conferences to discuss critical issues bothering women and how their situations can improve in order to achieve gender equality and equity. These various conferences led to and enhanced the interactions of women. The 1975 International Women's Year was among the global initiatives to address gender inequalities (UN,1990). Ten years afterward, the United Nations Decade for women was established to fight discriminatory practices against women. Three major objectives related to gender equality, peaceful environment, and gender and development for the decade were identified (Catagayet.al, 1986). These included giving both men and women equal representations, opportunities, and choices. In July 1980, the second world conference on women was held in Copenhagen to address gender disparities and women's rights. In addition, transnational feminism has had a strong intellectual impact on the field of feminism and gender studies (Nagar and Swarr, 2010) and its goals have been diffused across the globe which has subsequently contributed to global knowledge production. Practically transnational feminism has transformed the discipline in such a way that more workshops are devoted to women issues than was the case in its early years. Women have achieved some of the key goals of global women's rights agenda, closing the gap in educational attainment which some feminists advocated for.

\subsubsection{Liberal feminist theory}

As the paper stated earlier, feminism focuses on basic assumptions that women in most societies are being marginalized, thus a strong need to change their status as well as the system. This movement is all about the strengthening or the empowerment of women. Although there are many variants of feminist theory, this paper identifies with the liberal perspective. This is because unlike the radical perspective which argues for a fundamental transformation of societal arrangement with respect to patriarchal structure encompassing the whole gamut of marriage, reproduction, sexual rights and so on, the liberalists believe that change in male-female relationship may be gradual. They argue that the two genders have roles to play in enhancing equal rights, thus the women should be given the same rights as men. 
Mary Wollstonecraft's (1759-1799) expositions are credited as the precursors of the liberal feminist movement. Her main argument was that women should also be educated just like the men so that they can be fulfilled. Liberal feminists, therefore, focused on the equal rights of both gender with more emphasis on women. These processes have, in recent times, been associated with globalisation which engenders these values. In this globalising process is the intense relationship across national boundaries, thus opening doors for new encounters as people interact with new cultures. Although these member states and their agencies now identify with the democratic principles in acknowledging the basic ideals of civil and political rights, the rate at which nations have implemented these principles and ideals vary. The extent to which these ideals are practiced in the various societies is hinged on the life chances which emanate from their various institutions. One of such institutions is the educational institution which the Women's Research and Documentation Center (WORDOC) typifies. What extent has this center, in more than three decades of its existence, been effectively impacted by trans-nationalism and how has it, in turn, contributed to the transnational phenomenon through knowledge production on women?

\subsection{Research methodology}

The research design adopted is a historical analysis of the development of transnational feminism. Data was collected through secondary sources using relevant published documents and pamphlets on the emergence and development of women and Gender studies centres to elicit necessary information. Three centres were purposively selected, these are; Women's Research and Documentation Center (WORDOC ), Institute of African Studies, University of Ibadan; Centre for Gender and Social Policy Studies(CGSP), Obafemi Awolowo University, Ile - Ife and Institute of Women, Gender and Development Studies, Federal University of Technology, Owerri. These centres were selected on the basis that they initially started as research centres and later birthed Gender studies academic programmes. The relationships between activities of the centres with transnational feminist activities are critically analysed with a view of interrogating the extent to which the latter impacted on the objectives of the former. Furthermore, the study examined how the centres' activities have enhanced knowledge production in Nigeria Universities

\subsection{Feminist Movements and their impact on knowledge production in Nigerian Universities}

The line of argument in this paper has been to identify and discuss the impact of the various feminist movements all over the world on the lives of women. These movements as discussed in the paper though started in the developed countries but eventually moved to third world countries. University education is an ideal environment for the production of scholarships on women and gender issues. Therefore, the women's studies are the academic arm of the women's movement in the 1960s and exist in tandem with feminist scholarship. It is a key example of new intellectual arena as it emerges as a study in Universities in Nigeria. Women's Studies functioned to develop a woman-oriented understanding of the world, to seek out the causalities for the oppression of women and examine the strategies for change. The field has been motivated to transform society in order to achieve equality for women (Mama, 1996). Gender studies emerged out of women's studies. Feminists, especially liberal feminists contended that the total liberation, equality, and development of women can best be achieved when both men and women are considered in the development process. Thus the philosophy of gender and development became prominent in the quest for women's development. Gender studies is not about women but about the relationship between women and men, boys and girls.

\subsubsection{Women's Research and Documentation Center (WORDOC) in the University of Ibadan}

The Women's Research and Documentation Center (WORDOC) is a University of Ibadan research centre that was established in 1987 by a group of female university scholars with the ultimate aim of producing knowledge on women's studies. WORDOC, being the first of its kind in Africa, is a national institution interested in the analysis of gender issues with respect to scholarship, socio-economic policy, and action. In addition, it aims at creating a focus for multidisciplinary study, action and discussions in all aspects of the lives of Nigerian women and provide a bank of knowledge where all materials gathered and published could be concentrated for the benefits of scholars and policymakers. The declaration of the United Nations Decade for Women (1975-1985) was a catalyst for developing Nigeria's interest in women's studies. By the time the United Nations Decade for Women was inaugurated, the seeds of women's activism had been sown in the politically active city of Ibadan and also at the University of Ibadan. To mark the UN Decade, the Institute of African Studies at the University of Ibadan organized a Women's Conference on "Rural Women and Agriculture" in 1985. Presentations and conference proceedings focused on the need to establish a research bureau and data bank as a crucial strategy for drawing together existing work and encouraging further research on women's issues. The networks created during the national conference led to the establishment of WORDOC in 1986 as a pioneering effort at the systematic collection of materials on women's studies. The activities of this centre led to the establishment of the Gender mainstreaming office at the University of Ibadan, which is responsible for the development of Gender policy in the university. 
Its activities have in a way been extended to knowledge production which had been its major fight over the years. As in subsequent centres discussed in this paper, the Gender Studies Programme, which runs academic postgraduate programme in the University of Ibadan, was established through WORDOC initiatives.

WORDOC holds annual conferences, workshops and seminars where critical issues affecting women are analyzed and deliberated. In addition, it serves as a rallying point for other international women's studies centers and related women's organizations on contemporary issues from time to time. In this way, WORDOC promotes liaison between women in academic and public life, and with other women organizations in order to promote a two-way interaction between the Centre and the community (Abanihe et al, 1990)

\subsubsection{Research Institutions}

This Association of African Women for Research and Development (AAWORD), a research centre, is an offspring of the strong activism of two major women's organisations in Nigeria: the liberal feminist organization -National Council of Women's Societies (NCWS) established in 1958, and the Socialist feminist group -Women in Nigeria established in 1992. These two organizations were established to fight for equality and bring awareness and change regarding women's oppression and exploitation (Awe and Mba,1991). Members of these groups such as Adetoun Ogunsheye and Bolanle Awe, took the initial step to embark on a critical study on the status of Nigerian women. Ogunsheye's work on the role and status of women in Nigeria (1960) and Awe's study of the Iyalode in the traditional Yoruba political system (1977) can be said to be the first research into the lives of women which helped expose feminist scholarship in Nigeria.

The establishment of AAWORD in 1977 was an outcome of the first national women's conference which was held in Ibadan, Nigeria in 1976. This, therefore, was a medium for the expansion of knowledge on feminism in both Nigeria and Africa. AAWORD was the first institution established in the African Continent by African women to produce research on African women and development.

\subsubsection{Centre for Gender and Social Policy Studies}

The Centre for Gender and Social Policy Studies, Obafemi Awolowo University was established in 1997 with a central focus on gender issues affecting women, with special focus on issues revolving around sexual and reproductive health. The center's activities include teaching, research, and training as well as outreach educational programmes. In addition, the center organises enlightenment and educative talks in primary and secondary schools. After some years of existence, the centre introduced academic programmes into its activities, such as certificate courses in Gender Studies and Social Development, as well as Postgraduate ccademic programmes.

\subsubsection{Institute of Women, Gender and Development}

The Institute of Women, Gender and Development is a multidisciplinary Academic Research unit domiciled in the office of the Vice Chancellor, Federal University of Technology, Owerri. It was established in 2010 and initially referred to as the Centre of Women, Child, Research and Development (CWCRD). In the year 2012, its name changed to Centre of Women, Gender and Development Studies (CWGDS) when it was granted full academic status and finally upgraded to Institution of Women, Gender and Development (IWGD) in 2015.

\subsubsection{Emerging Gender Centres}

In sum, and according to Abanihe et.al. (1999), feminism is a means to an end and the end is that women should be able to realize their full potential and contribute fully to the development of the country. Even though WORDOC took the initial step in Nigeria to react to the deliberations of the different conferences, other universities have also adopted and established women studies centers where studies on various women issues are undertaken.

Some examples of new centres of such universities are;

1. Centre for Women and Gender Studies, Imo State University

2. Centre for Gender Studies, University of Uyo, Uyo

3. Centre for Gender and Women Studies, University of Jos

4. Centre for Gender and Development Studies, Ekiti State University, Ekiti

5. Centre for Gender Studies, Bayero University, Kano

The research centres were not only established in the universities but departments also inculcated gender issues into their curriculum and this cuts across different disciplines. 


\section{Conclusion}

The field of gender studies and research centers is an outcome of the transnational feminist movement for the expansion of scholarship on women. The relevance of women centres to feminism lies in the fact that feminism has different forms and it deals with different issues and adopts different strategies according to the nature of the context within which it operates. Thus it should not be viewed as an international prescription from the West to the rest of the world, especially Africa, even though there is a need for cross-culture alliance.

\section{References}

AAWORD,(1983). Seminars on Research on African women. What type of methodology? Occasional paper series, No.1. Dakar, Association of African Women for Research and Documentation

Abiola, H.(2006). Edge of the Earth' in Janet Lee and Susan Shaw, Women Worldwide, Transnational Feminist perspectives on women. Oregon StateUniversity:McGraw Hill

Adjepong, A. (2016). The Role of Women in the Political Development of Pre-colonial Africa". In S. Ademola Ajayi and J. Kehinde Ayantayo, eds. Women in Development Yesterday and Today: Essays in Memory of Professor Dorcas Olubanke Akintunde. Ibadan: John Archers (Publishers) Limited, 2015. pp. 17-40.

Akorede,Y. (2011). Womanism and the Intra-Gender Conflict Theory.Porto -Norvo: Sonou Press,

Awe, B. (1996), A Brief overview of Nigerian women studies in A. Mama ed.Setting an Agenda for Gender and women's studies in Nigeria. Report of the Network for women's studies in Nigeria. No.1, Zaria.

Awe, B., (1977). The Iyalode in the Traditional Yoruba Political System, in Alice Schegel ed. Sexual Gratification; A Cross Cultural View. New York; Columbia University Press.

Awe, B.(2001), "Iyalode Efunsetan Aniwura" in B. Awe, Women in Historical Perspectives 2nd ed. Ibadan, Lagos: Bookcraft , Sankore

Baksh, R.,and Harcourt, W., eds. (2015). The Oxford Handbook of Transnational Feminist Movements. USA: Oxford University press.

Banks, O. (1980), Faces of Feminism. Oxford: Martin Robertson

Baumgardner, J. (2011). F'em: Goo Goo, Gaga and Some Thoughts on Balls.USA: Seal Press

Beckwith, K. (2002). Beyond compare? Women's movements in comparative perspectives'European Journal of Political Research 37(1):31-8

Bock, G.(2002).Women in European History. Oxford: Blackwell

Bryson, V. (1999). Feminist Debates, Issues of Theory and Political Practice. Hound mills; Macmillan

Bryson, V. (2003). Feminist Political Theory: An Introduction $2^{\text {nd }}$ ed. Basingstoke: Palgrave, Macmillan.

Catagay, N. and Grown, S. (1986). The Nairobi Women's Conference. Towards a Global Feminism. Feminist studies 12 (2): 401-412

Claire, S. (2008). What is the Third wave Feminism: A new direction.Signs. 34, (1)

Connell, R., (2014). The Sociology of Gender in Southern Perspective Current. Sociology, 62(4), 550-567

De Beauvoir, S. (1953), The Second Sex. London; Jonathan Cape

Di Marco, G. and Tabbush, C.eds. (2011). Feminism Democratization and Radical Democracy: San Martin. Argentina: UNSAMEDITA press

Evans, S. (2003).Tidal Wave How women changed America at Century's end.New York: Free press

Falcon, S. (2012). Transnational Feminism and Conceptualized intersectionality at the 2001 World Conference against Racism.Journal of Women's History Winter.Vol. 24, (4): 99-120

Ferre, M., and Tripp Alli, M. eds. (2006).Global Feminism. Transnational Women's Activism, Organizing and Human Rights. New York and London: University Press.

Fourth World Conference on women: Beijing, China. September 1995. Action for Equality, Development and Peace.[Online] Available: http://enb.iisd.org/download/pdf/enb1421e.pdf(August 2019)

Freedman, J., (2001), Concepts in the Social Sciences Feminism. Buckingham, Philadelpha: Open University Press.

Freeman, J. (1995), Beijing Report. The Fourth World Conference on Women. China: Beijing

Friedan, B. (1963)The Feminist Mystique. New York: Dell

Gamble, S., ed. (2001) Feminism and Post Feminism. London: Routledge

Gerhard, H. 2002, "The women's movement in Germany", in Giffin, G. and Braidoffi, R. eds. Thinking Differently: A Reader in European Women's studies. London. Zed books

Gills,S., Howie, G., and Munford, R., eds. (2004) Third Wave feminism: A Critical Explanation. Hound mills: Palgrave Macmillan

Hannam, J. (2007) Feminism. United Kingdom: Pearson Longman. 
Hasso, F., 2001 The Long term Impact of Social movement involvement on Palestinian Women's Lives' American Journal of Sociology Vol. 107, No.3. November 586- 611

Hawkesworth, M., (2006) Globalization and Feminist Activism. Rowan and Littlefield

Hewith, N., (2010), No Permanent Waves. Recasting Histories of US Feminism. Rutgers University press.

Hill - Collis., P.,(2000) Black feminist Thought: Knowledge, consciousness and the politics of empowerment. New York: Routledge

Isiugo-Abanihe, I. Udegbe, B. Olaoba,F. and Oyelude,A. (1999), Bolanle Awe: Portrait of an Academic and Activist. Ibadan; Nigeria: WORDOC

Jo Freeman,(1995), Beijing Report : The Fourth World Conference on Women. China: Beijing

Laut, J.(2014),"Unsettling the Discipline: Rethinking transnational feminism" Women's Studies Quarterly Vol.42, Nos. 3-4. Fall/ winter:320-322

Lerner, G., (1993),The Creation of feminist consciousness: From the middle ages to Eighteen Century

Maghadam, V. 2013 Globalizaton and Social Movements; Islamism, Feminism and Global Justice movement 2nd ed. Lanham, MD: Rowman and Littlefield

Mama, A.(1996), Women's studies and studies of women in Africa during the 1990s CODESRIA Working paper series $5 / 96$

Mendoza, B. (2002) 'Transnational Feminism in Question,' Feminist Theory, Vol. 3(3): 313 - 332

Millet, K.(1969). Sexual Politics: London; Ruppert Hart- Davies

Mitchell,J.(1997) Women's Estate,Harmondsworth: Penguin

Motta, Sara, Fominaya, C. Eschle, C. and Cox, L. (2011), "Feminism Women's Movements and Women in Movements" Interface: A journal for and about social Movements Vol. 3(2): 1- 32.

Mukherjee, D., (2008) Feminism: Theories and Impact. Hyderabad; The Icfai University Press

Ogusheye, A.,(1960) "Role and status of women in Nigeria" Presence Africaine, 4.

Rampton, Martha 2015). Four waves of feminism.[Online] Available: https://www.pacificu.edu/about/media/fourwaves-feminism(August 2019)

Randall, J. (1 985) The Origins of Modern Feminism: Women in Britain, France and the United States, 17801860. Basingstoke; Macmillan

Reilly, N. (2011). Doing Transnational Feminism, Transforming Human Rights: The Emancipation Possibilities Revisited ' Irish Journal of Sociology, Vol. 19(2):60-76

Roces,M. and Edwards, 1. 2010 Women's Movements in Asia: Feminisms and Transnational Activism. London. Routledge

Rowbothan, S. (1989) The Past is before us. Feminism in Action since the 1960s. London. Pandora

Rowbothan, S.(1973) From History, 300years of Women 's oppression and the fight against it. London: Pluto

Rupp, L.(1997)Worlds of women: The making of an International movement. Princeton. NJ. Princeton University press

Smith, H.L ed. (1990) British Feminism in the Twentieth Century. Alder shot: Edward Elgan

Summers, A.(2000). Female lives, moral states. Newbury. Threshold press

Thompson, B.,(2010),"Multiracial Feminism" in Nancy Hewith

Tripp, Ali,M.(2005.)Regional Networking and Transnational feminism: African Experiences Feminist Africa 4: 1 -12.

Whelehan, I.(1995), Modern Feminist Thought .From Second Wave to Post Feminism: Edinburgh: Edinburgh University press.

Woolf, V.(1941), A Room of One's Own, London, Hogarth press 